\title{
手根管症候群における新しい皮切の経験
}

\author{
熊本機能病院整形外科 \\ 平 野 哲 也・中島 英 親 \\ 加藤 悌二・米満弘之
}

\section{Clinical Study of New Skin Incision for Carpal Tunnel Syndrome}

by

\author{
Tetsuya Hirano, Hidechika Nakasima, Teiji Katoh \\ and Hiroyuki Yonemitsu \\ Department of Orthopaedic Surgery, \\ Kumamoto Kinoh Hospital
}

\begin{abstract}
We treated 53 carpal tunnel symdrome patients from August 1990 to April 1993 using our new skin incision procedure.

This incision can resect the transverse carpal ligament permitting decompression of the median nerve without crossing the distal wrist crease.

Post-oper atively no patient has any complications such as painful hypertrophic scarring.
\end{abstract}

Key words : Crapal tunnel syndrome (手根管症候群), Median nerve (正中神経), Skin incision (皮 切), Distal wrist crease (遠位掌側手首皮線)

はじめに

手根管症候群に対する手根管開放術においては, 皮 切が遠位掌側手首皮線と交差することにより，術後に 有痛性の肥厚性疲痕（図 1) をきたすことがあり問題 となる。これに対し，各種方法が報告されている3゙ が, 今回私達は, 前腕部皮切において, 横手根靯帯, 正中 神経掌側枝を確認後, 遠位掌側手首皮線に皮切を加え ず手掌部皮切において，手根管を開放する皮切を試み たので報告する。

\section{対}

象

平成 3 年 8 月より平成 5 年 4 月までの 1 年 8 カ月の 間に計 53 例 66 手（男 4 例，女 49 例，右 16 例左 24 例両側 13 例) 平均年齢 55.5 歳, 29 歳 80 歳に対し て本法を施行した。発症から手術までの期間は 2 力月 から 4 年である. 全例正中神経領域に知覚障害が存在
しており，母指球筋に明らかな萎縮を認めるものは 32 手, 夜間痛を訴えるものは 25 手であった。術前 $\mathrm{M}$ 波の終末潜時 $4.5 \mathrm{msec}$ 以上を手術の判断基準とした. 全例に本皮切を施行し, 従来法 (遠位掌側手首皮線に 切開を加えたもの）と症状合併症, 所用時間, 創痛, 有痛性肥厚性瘷痕等を検討した。腎透析患者, 拇指対 立再建を行ったものは除外した。

手術手技

（図 2 ）の如く遠位掌側手首皮線を避け, 前腕部, 手掌部に二ヶ所の皮切をデザインする. 手掌部皮切は 手掌中央部からゆるい尺側凸の皮切で掌側枝保護のた め尺側へ斜走させる。これに対応した形で前腕部皮切 をデザインし間に $1 \mathrm{~cm}$ の皮下トンネルを作成する。 前腕部皮切より長掌筇腱, 正中神経掌側枝, 横手根靯 帯を確認する. 前腕部にて切離した長掌筋腱を皮下卜 ンネルに通し, 手掌部において aponeurosis を切離す る. 前腕部より神経の尺側部で掌側手根靯带, 横手靯 


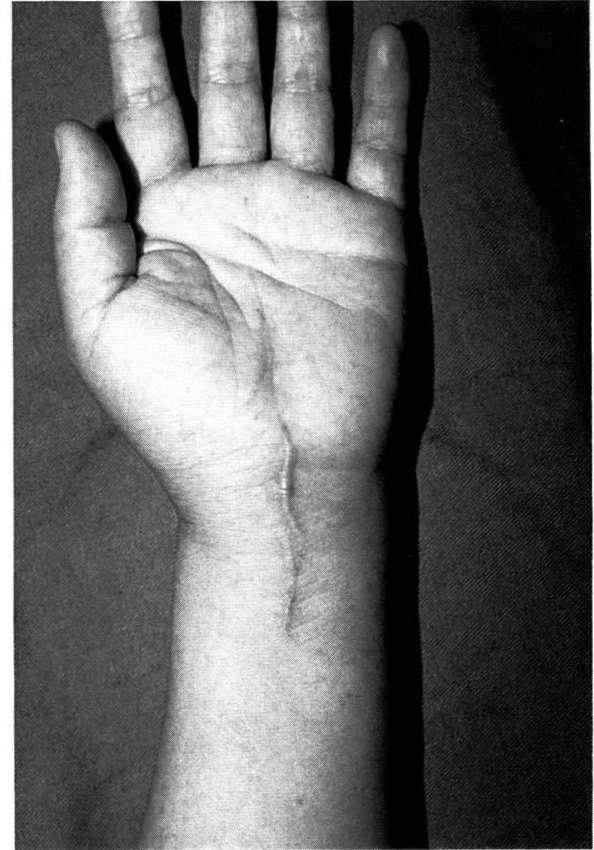

図 1 有痛性肥厚性痈痕

皮切が遠位掌側手首皮線と交差することにより有痛性 肥厚性瘢痕を生じることがある。

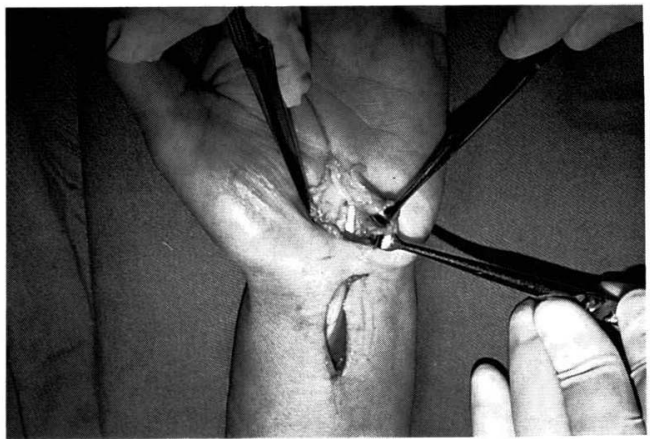

図 3 手根管の開放

前腕部皮切より神経の尺側部にて掌側手根鞀帯・横手根鞀 帯を切離する。

帯を末梢へ切離していく4．（図 3 ）この際掌側枝, 運動枝及び異常筋の有無に注意し，滑膜に増殖があれ ばこれを処置する、鞀帯の縫合は行っておらず，全例 internal neurolysis は行っていない.

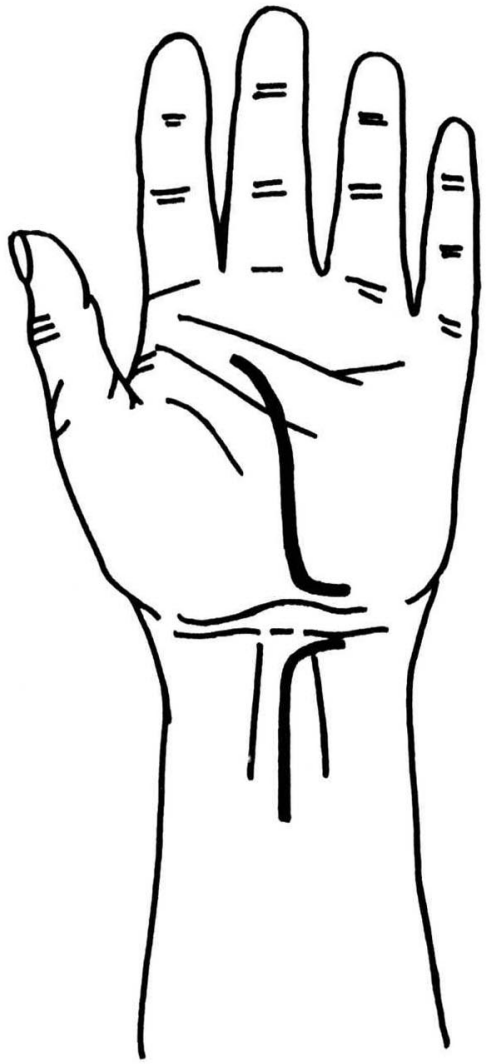

図2 皮切

遠位掌側手首肥線を交差しないよう手掌部・前碗部二ク 所に皮切をおく.

結

果

術後, 有痛性の肥厚性痏痕をきたしたものは 1 例も なかった。術後の創痛も 2 例に軽い創痛をみたが， 3 週以内に軽快し, 従来法に比較し訴えが少なかった。 反対側に従来法を施行した症例に扮いても本法側の方 が創痛が軽度であった。夜間痛も全例早期に軽快し, 知覚障害等症状の改善も良好であった。神経血管損傷 等の合併症もなく, 屈筋腱の bow-string ${ }^{2)}$ や術後 3 〜 6 力月たった症例においては握力低下も認めなかっ た。術後M波，終末潜時の改善も従来法との差を認め なかった。平均所要時間は, 本法 33.8 分, 従来法 25 分であった。 


\section{考察}

手根管症候群に対する手根管開放術においては, 手 掌部より前碗部にかけて皮切遠位手掌手首皮線を交差 することにより術後有痛性の肥厚性瘚痕をきたすこと があり，術後機能訓練や ADL に支障を生じることが ある. 私達の施行した皮切は遠位掌側手首皮線に切開 を加えないため有痛性肥厚性疫痕を生じることはなかっ た，又，手掌部のみでなく，前碗部にも皮切を加える ことにより正中神経, 横手根勒帯をより確実に確認で き同部における長掌筋, 正中神経掌側枝, 運動枝の位 置異常や異常筋の有無等の解剖学的変異 11 に対しても 処置することが可能である. 横手根勒帯の変性や滑膜 の増殖など神経の圧迫要因となる因子に対してもより 適切に処置できると考える. 従来法と比較して若干時 間がかかる傾向であるが，手技に習熟すれば，両者の 差は更に短縮できるものと思われる，手根管症候群に おいては, 神経の除圧のみならず，早期の ADL 復帰 という観点より術後創痛等にも注意を払う必要がある と考えられる。

$$
\text { ま と め }
$$

1. 手根管症候群に対する新しい皮切を試みたので
報告した。

2. 皮切が遠位掌側手首皮線と交差しないため術後 有痛性の肥厚性瘷痕をきたすことがなく術後創痛もな かった。

3 . 症状の改善, 合併症伴に従来法と差はなく, 平 均所要時間も 33.8 分, 従来法 25 分と大きな差はなかっ た.

4. 前碗部に皮切を加えることにより，正中神経， 横手根勒帯を確実に確認でき, 正中神経掌側枝, 運動 枝の位置異常, 長掌筋, 異常筋の有無等, 解剖学的変 異に対しても，対処することができる。

\section{参 考 文 献}

1）樋口出 ら：正中神経母指球筋枝の分岐, 走行に関す 了解剖学的検討, 整形外科, $27: 1242-1244,1976$.

2) MacDonald, R. I., et al. : Copliations of surgical release for carpal tunnel syndrome. J. Hand surg., 3 : 70-76, 1978

3）塩田悦二, 友兼尚之, 岩松陽一郎：Carpal tunnel Syndromeに対する新しい手根管拡大術の経験. 日手会 誌, $9: 417-420,1992$.

4）津下健哉：手根管症候群。手の外科の実際（第 6 版), 397-401. 東京, 南江堂, 1985 . 